\title{
Influence of Globalization on Development of the Russian Economy
}

\author{
D. Kh. Gallyamova \\ A.R. Toumashev \\ V.V. Malaev \\ Kazan (Volga region) Federal University, 18, Kremlyovskaya Street, Kazan, \\ Repablic of Tatarstan, Russian Federation, 420008
}

\section{Doi:10.5901/mjss.2014.v5n18p133}

\begin{abstract}
Article contains theoretical and practical analysis of development of international cooperation of Russia within globalization process. Important element of globalization for the Russian economy is economic integration within foreign trade cooperation of Russia. Consideration of positive and negative scenarios of development of situation in the foreign trade segment of the Russian economy is a basis for allocation of the basic parameters providing or interfering stable economic development. Consequences of strengthening of processes of globalization concerning the Russian economy during the period since 2012 allow to estimate features and directions of deepening of integration of Russia in world economy, and to reveal the indicators demanding special control from the state.
\end{abstract}

Keywords: globalization, international integration, Russia, foreign trade cooperation, economic development, economic growth

\section{Introduction}

Modern globalization can be defined as process of formation of the uniform universal information and financial space, caused by development of electronic means of communication, transfers, storages and data processing. As $\mathrm{M}$. Kastels [1] noted, information economy by the nature is global as it allows operating in each time point in worldwide scales. Collapse of the USSR and the Soviet block finished globalization territorially, opened possibilities of distribution of institutional norms of the western civilization the whole planet.

If in the middle of the XX century the states and the structures mediated by them were the main subjects of international relations, now their place are taken by multinational corporations and international financial centers. This tendency which is showed in the international cooperation in all spheres of economic and political life, can be defined as transition from classical foreign policy to world domestic policy [2].

Rapid development of multinational corporations promoted high volumes of foreign investments. In 2000 total amount of transnational direct investments around the world exceeded 1,3 trillion dollars which meant its doubling in comparison with 1998. Further, in 2007 the indicator grew by 29,9\%, having reached 1,83 trillion dollars. Due to the world financial and economic crisis in 2008, by UNCTAD estimates, reduction of inflow of direct foreign investments for $21 \%$ (to 1,45 trillion dollars) is noted. Against macroeconomic instability and political uncertainty in the next years reduction of total amount of direct foreign investments was observed. So, in 2012 this indicator decreased by $18 \%$ in comparison with previous year and made $\$ 1,35$ trillion.

\section{Theory}

The variety of theoretical views of globalization, their detailed analysis contains in works of Guillermo De la Dehesa [2-3], Stanley Fischer [4], and other authors [5] [6]. Supporters of globalization pay attention to its conditionality by natural movement of capitals and increasing dependence of national economies on the global financial markets and multinational corporations and offer effective mechanisms of international integration in financial and economic spheres [7-8]. In their opinion, globalization in long-term prospect allows to use advantages of the international division of labor, to create global system of cooperation communications (supply chain) [9] and to increase efficiency of functioning of the world economy.

Opponents of globalization controvert the state of its natural character. Following Jacques Derrida of [10], critics of globalization try to prove that behind opening of economic borders there are forms of hegemony [11] about which as 
about economy of the dominating force in relation to France of the middle of the XX century François Perroux wrote allocating centers of growth and periphery [12].

In compliance with this approach economic subjects are initially unequal and connected with each other by the taxonomy relations which are formed in process of growth of the sizes of companies. Globalization of economy brings this process to the world level.

In practical implementation globalization has to solve a number of interconnected tasks.

The first is ensuring bigger transparency to which serves process of expansion of the WTO and the regional economic unions, and also activity of such organizations as the IMF, World bank.

The second - providing uniform rules of law of maintaining international economic relations and creation of international institutes providing their performance, including increase of a role of international arbitration courts.

The third - universalization of standards and regulations of economic activity, having impacts on unification of other parties of social life, upbringing and education.

The fourth - need of the organization of the universalized system of calculations and payments which has to correspond and financially provide functioning of global economy.

Within the real work attention is paid to the sphere of the foreign trade relations of the Russian economy. In this context WTO can be considered as the imported institute which passes a stage of intensive adaptation in Russia.

For definition of consequences of globalization for economy of Russia potential opportunities and threats are considered which the accelerated adoption of institutional requirements imposed by the entry of the country in the WTO can represent for its economy.

\section{Results}

On condition of implementation of the positive scenario of development the advantages of entrance of the Russian economy in the WTO will be:

- Expansion of a sales market of production of the Russian production and improvement of structure of export. "Actually accession to WTO is the first powerful measure for advance of the Russian export", - noted professor of the Russian Economic School (RES) Natalya Volchkova. Positive expectations concern generally export of the Russian metals (ferrous and nonferrous metallurgy) on which import the USA has restrictive quotas, and petro-chemistry production.

- Inflow of foreign investments, preferably direct, owing to bigger security of investors by the international obligations of Russia and inadmissibility of providing direct preferences to residents. "Stabilization of a trade policy will be able to make Russia more attractive to foreign investors", - the expert of New Economic School estimated possible prospects.

- Decrease in internal prices as a result of reduction of import customs duties on imported production and toughening of conditions of competition for domestic producers;

- Improvement of dynamics of the main macroeconomic indicators owing to growth of business activity of exporters, foreign and domestic investors.

- Increase of level of the legal and business culture connected with more active cooperation with leading foreign firms, inflow of new technologies and development of progressive modern methods of management, decrease of corruption.

- Increase in a role of innovative component in development of the Russian economy.

About the last position it should be noted the following. The correlation analysis of statistical data of the Republic of Tatarstan carried out by us showed that rates of development of extracting branches have direct dependence with rates of changes of size of investments into fixed capital (correlation 0,66 ) while branches of manufacturing industry have the return correlation with the size of investments into fixed capital (correlation-0,71). Branches of extracting sector of economy have correlation with rates of changes in the size of the shipped innovative goods. As the export sector of Russia includes mainly export of raw materials, innovations in Russia tend to concentrate in export branches and pursue the aims of increase of efficiency and productivity at raw materials production. Thereby primary development of innovative process in raw sector of economy (which shows weaknesses of manufacturing industry) is provided $[13,16]$.

Expected advantages of Russia's entry into the World Trade Organization to agriculture are possible improvement of conditions of access of the Russian agricultural production (mainly grains) to the world market and inflow of the foreign capital. At Russia's entry into the World Trade Organization the agreement on admissible level of state support of national agrarian production of 9 bln. dollars with its practical reduction by $50 \%$ by 2018 was reached. The problem is that within the current situation for 2013-2014 agriculture subsidizing from the state will make 130 billion rubles that is much less, 
than the limits of subsidizing provided by the agreement with the WTO. Growth of subsidizing is supposed during the subsequent period of time when according to the accepted obligations there will have to be a reduction of its sizes.

Already at a stage of negotiations on Russia's entry into the World Trade Organization it was supposed that Russia recognizes that other members of the WTO can apply more widely tariff regulation (Table 1).

Table 1.Extra quote rates of a customs tariff, \% ( World-Tariff-Profiles,WTO- 2010).

\begin{tabular}{|l|c|c|c|}
\hline \multirow{2}{*}{ Виды продукции } & \multicolumn{3}{|c|}{ Protected food market } \\
\cline { 2 - 4 } & RF & EU & USA \\
\hline Milk and dairy products & 19 & 163 & 126 \\
\hline Vegetables, fruit and live plants & 36 & 161 & 132 \\
\hline Sugar and confectionery & 68 & 118 & 79 \\
\hline Vegetable oil & 24 & 94 & 164 \\
\hline
\end{tabular}

Considering the general specifics of development of the Russian economy during the period before entry into the WTO, we determined the basic parameters influencing development of national economy and there was constructed a model showing dependence of rates of change of gross domestic product of Russia from growth rates of receipts from export (X1), unemployment rate (X2), investments into fixed capital (X3).

$$
y=1,04 \frac{x_{1}^{0,18} x_{3}^{0,15}}{x_{2}^{0,33}} \varepsilon
$$

These parameters define rates of changes of gross domestic product (show the big importance within model). Russia's entry into the World Trade Organization according to the experts will affect these parameters (directly - export receipts and investments into fixed capital and indirectly - unemployment rate).

The narrowness of the general influence of all parameters on rates of change of gross domestic product can be estimated as high $-68 \%$ of a variation of rates of change of gross domestic product are caused by change of these parameters.

The negative scenario of development of situation in the Russian economy in intensification of process of globalization assumes the following threats:

1. Absorption or reduction of domestic financial institutions. The probability of it decreases a little owing to reached within the held negotiations on Russia's entry into the World Trade Organization agreements on their protection (foreign banks are forbidden to open the branches in Russia, opening of subsidiaries is allowed only).

2. Significant increase in outflow of capital from the Russian economy in the absence of significant direct investments to Russia. Formally according to UNCTAD experts inflow of capitals to the Russian economy for 2013 grew by $83 \%$ and made 94 billion dollars (the third place in the world). However only $5-6 \%$ of these funds represent real capital investments, for $92-95 \%$ they are credits and loans which mainly go for repayment of earlier taken credits and financial speculation. According to Bank of Russia pure export of capital by banks and enterprises from Russia grew from 54,6 billion dollars in 2012 to 63,7 billion in 2013 [11, 14].

3. Decrease in competitiveness of domestic enterprises due to reduction in cost of imported goods, and, as a result, deterioration of conditions of activity of a number of branches of the Russian industry, agriculture, and services sector. The Russian economy isn't in a phase of steady growth, therefore isn't completely ready for opposition to foreign competition [15].

4. Increase in outflow of the qualified labor. This scenario is rather realistic as labor, especially highly skilled, also as well as the capital is capable to be mobile, and, therefore, can dodge taxes and go to another countries that is confirmed by practice of East European countries - new members of the European Union.

5. Cardinal distinctions in compensation level in different countries in conditions of globalization led to outflow of the capitals, moving of production to countries with traditionally lower level of salary.

6. Considering dynamics of quarterly growth rates of gross domestic product of the Russian economy, it is possible to track situation deterioration since 3 quarters 2012 (Fig. 1). 


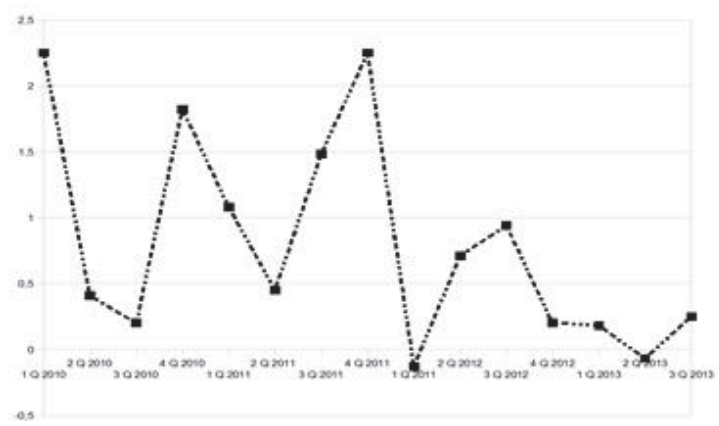

Fig. 1. Dynamics of growth rates of gross domestic product in Russian economy (as a percentage quarterly in prices of 2008 , billion rubles) with an exception of a seasonal factor.

Expected parameters weren't reached, and dynamics of quarter growth rate of gross domestic product shows their falling, since 2012 (Fig. 2).


$\% \mathrm{~A}$ - gain to the respective quarter of the current year, $\mathrm{B}$ - gain in the last quarter, $\%$

Fig. 2. Dynamics of quarter growth rate of gross domestic product

\section{Conclusions}

Following the results of the first year of Russia's stay in the WTO significantly the following changes which have happened in the sphere of foreign economic activity of Russia:

1. Within the signed agreements on entry into the WTO the import duties on a number of foodstuff decreased: on imported pork on quotas from 15 to $0 \%$, and over a quota from 75 to $65 \%$, on dairy products from 25 to $15 \%$. As a result in the fall of 2012 import of pork, milk, cheeses (116\%) and butter (136\%) grew, import of powdered milk (216\%) increased. According to Institute of an conjuncture of the agrarian market import of vegetable oil (50\%) and tobacco products (33\%) increased also. In Russia there was a reduction of prices in the market of production of animal husbandry (and its prime costs for the majority of the Russian producers are lower). For situation smoothing in a transition period the ban on import of the cooled and frozen meat from a number of countries (because of hygienic requirements) was imposed. As a result at the beginning of 2013 deliveries of pork to Russia from Germany fell.

2. The debt on salary increased from July, 2012 to August, 2013 by $25 \%$. During the summer of 2013 unemployment grew by $8 \%$. In industrial production for 2013 zero growth was observed.

3. Introduction of utilization collecting on imported cars after entry into WTO led on September 1, 2012 to submission of the first claim within the WTO to Russia. Collecting is directed against cars of foreign production and is used with the same purpose, as import duties. In compliance of the new requirements planned 
introduction of similar collecting for resident car makers.

Consequences of Russia's entry into the WTO are inconsistent. Despite a number of positive results of activity of the international companies and institutes in Russia the aggravation of "internal diseases" of its national economy is observed.

\section{References}

Gainova R.A., Shaidullin R.N., Safiullin L.N. and Maratkanova E.M. Infrastructural Component in Maintenance of Competitiveness of Region// World Applied Sciences Journal, 27(13), 2013, pp. 97-101.

Safiullin M.R., Samigullin I.G. and Safiullin L.N. Model of Management of Competitiveness of a Machine-building Complex// World Applied Sciences Journal, 27(13), 2013, pp. 212-216.

Askhatova L.I., Fatkhiev A.M., Safiullin L.N. and Safiullina A.M. Competitive Strategies Formation in High Technology Enterprise // World Applied Sciences Journal, 27(13), 2013, pp. 20-23.

Castells, M. The Rise of the Network Society, Maiden (Ma.) - Oxford: Blackwell Publishers, 1996, p. 92.

De la Dehesa, Guillermo. Winners and Losers in Globalization. Blackwell Publishing., 2006. - 252 p.

Bagautdinova, N.G., Malakhov, V.P., Kundakchyan, R.M. Development of management system of manufacturing companies on the basis of management accounting elements // World Applied Sciences Journal, 27(13), 2013, 53-57.

Weinstein, Michael M. Globalization: What's New? Columbia University Press, 2005. - 279 p.

Manfred B. Steger: Globalism: The New Market Ideology. Rowman \& Littlefield Publishers, 2002. - 195 p.

Soros, G. George Soros on Globalization, Oxford: Public Affairs, 2002. - 160 p.

Irwin, Douglas A. Free Trade Under Fire. Princeton University Press, 2nd edition, 2005. - 257 p.

Alexander V. The Problem of Optimal Exchange Rate For Central European Countries /Volbert Alexander // Postgraduate Research Program "Capital markets and Finance in Enlarged Europe", Working Paper Series., № 1/2001. - pp.1-30.

Sarkin, A.V., Bagautdinova, N.G., Averianov, B.A. Development and implementation of adaptive science-intensive manufacture management system based on management processes automation // World Applied Sciences Journal, 27(13), 2013, 159-164.

Isaeva, T.N., Safiullin, L.N., Bagautdinova, N.G., Shaidullin, R.N. Aspects of a multi-level study of competitive performance of objects and subjects of economic management // World Applied Sciences Journal, 27(13), 2013, 116-119.

Ajupov A.A. The Design and Use of Swap-Contracts in the Financial Markets // World Applied Sciences Journal, 27(13), 2013, pp. 1-4.

Glebova I.S., Sadyrtdinov R. and Rodnyansky D. Impact Analysis of Investment Attractiveness of the Republic of Tatarstan on Fixed Investments of its Leading Companies // World Applied Sciences Journal 26 (7): 911-916, 2013.

Jacques Derrida. La Mondialisation, la Paix et la Cosmopolitan . A Speech at Headquartes of UNESCO in Paris on December, 1999., published in Regardes, February 1, 2000. 
